\title{
The Secret of Judgment in Hannah Arendt
}

\author{
Yafeng Dang \\ Beijing Normal University, Beijing, China \\ Email: dyf815leo@163.com
}

How to cite this paper: Dang, Y.F. (2019)

The Secret of Judgment in Hannah Arendt. Open Journal of Social Sciences, 7, 18-25. https://doi.org/10.4236/jss.2019.711002

Received: October 21, 2019

Accepted: November 10, 2019

Published: November 13, 2019

Copyright $\odot 2019$ by author(s) and Scientific Research Publishing Inc. This work is licensed under the Creative Commons Attribution International License (CC BY 4.0).

http://creativecommons.org/licenses/by/4.0/

\begin{abstract}
According to revisiting what Arendt has written, this article brings out the secret of judgment in Arendt through investigating the relevant themes which involve freedom, opinion, and taste. Freedom, to be more specific, public freedom, is the context of judgment. Judgment is the activity that fits into the public realm where freedom becomes visible to all. Opinion constitutes the object of judgment. Judging, which is the representative thinking, makes the standpoints of others present to our minds, then to form an opinion means to judge a given issue basing on different viewpoints. The validity of judgment depends on the ability of taste. More precisely, taste; that is, the power of judgment; defines the specific validity of judgment which is distinguished from other validities of authority, force, strength, and violence. In summary, Arendt's judgment is the power of taste which guarantees the validity of opinion in the context of public freedom.
\end{abstract}

\section{Keywords}

Judgment, Freedom, Opinion, Taste

\section{Introduction}

As Richard J. Bernstein said in Why Read Hannah Arendt Now, although the world has changed significantly since Arendt died in December 1975, what she had written turns out to be even more relevant for us today. "Arendt was remarkably perceptive about some of the deepest problems, perplexities, and dangerous tendencies in modern political life. Many of these have not disappeared; they have become more intense and more dangerous." [1]. In this sense, it is important for us to return to Arendt's political motifs, especially the concept of Judgment. However, even though there has been a considerable amount of attention to Arendt's theory of judgment in political theorists, such as Richard J. Bernstein, Ronald Beiner, George Kateb, Jürgen Habermas and Linda Zerilli, it is 
still a challenging task to comprehend the concept of judgment in Arendt's writings. There are at least two reasons which we can speak. First, in advance of her essays in Between Past and Future, Arendt referred to judgment occasionally. Second, as it is known to us, judgment was to be the third part of Arendt's plans in Life of the Mind which she did not live to complete. Just because of these scholarly difficulties, Richard J. Bernstein pointed out that there was a deep contradiction between judgment in vita activa and judgment in vita contemplativa; Ronald Beiner thought that Arendt in her later works displaced judging from the actor to spectator; George Kateb proposed that Arendt aestheticized politics so that it became morally dangerous; Jürgen Habermas criticized Arendt for neglecting the function of distinctiveness dealing with different opinions; and Linda Zerilli suggested that Arendt's judgment was not complete. In the present paper, however, I will seek to provide some defensive understanding of Arendt's Judgment that insofar as we focus our attention on the highest form of human activity-action, i.e. praxis, which differs from labor and work in The Human Condition-it is possible to make judgment explicit. In particular, Freedom sets our context to appreciate judgment; opinion is the object of judgment; and taste plays the role of the power of judgment.

Freedom: The condition sine qua non for Arendt's Judgment is Public Freedom. For Arendt, judgment means to transcend itself from "idiosyncrasies" or "individual privacy" and to enter into "the market place" or "the public realm" [2]. There are two respects here I want to indicate concerning Public Freedom. On the one hand, to say freedom is public is to say that freedom is the attribute of community but not of men. On the other hand, public freedom is not limited to the few but is for all of people. Only in the sense of Public Freedom can we appropriately apply Arendt's Judgment to its context. Gadamer has conducted us, the pre-understanding, that is, context, is prerequisite for our understanding activity. So it is consequential at the beginning to uncover the context of Arendt's Judgment in order to understand it properly.

Opinion: In Arendt's view, judging at the same time is the formation of opinion. Opinion firstly is different from truth which is the sort of "rational truth" that inspires pure philosophers or the sort of empirical truth of "fact gatherers" [3]. Secondly, opinion also should be distinguished from interest. Interest always represents some group interests even it happens to be that of the majority. To say opinion is different from truth is not to deny the relevance of truth and fact or the validity for opinion but to wary us to discriminate two kinds of validity. For opinion, it is the plurality and variability that is essential and nonreducible. As to the distinction between interest and opinion, contrary to interest which cares only about some group interests, opinion exclusively calls attention to individuals who consist of all people.

Taste: Arendt, who is deeply influenced by German philosophy tradition, drew on the concept of taste which derived from Kant in Critique of Judgment to articulate what she intended to say concerning Judgment. Taste does not refer to some private feelings or certain type of universals characteristic of "cognitive 
reason". On the contrary, taste denotes sensus communis, which is the sense of community that helps us fit into human community. In other words, taste is not that of strength, authority, force and violence but the power which is only possible through participation. Accordingly, taste, like freedom and opinion, belongs to all of us. However, it is misleading to simply identify Arendt's taste with Kant's taste. "Kant was primarily concerned with the disinterested judgment of the 'pure' spectator, not with that of the participant in human affairs." [4]. For Arendt not the pure spectator but the participant is the bearer of the power of judgment.

\section{Freedom: The Context of Judgment}

All of what we can say about Arendt's Judgment could begin with a truism that Arendt almost casually said that "debate constitutes the very essence of political life." [5]. This truism makes it necessary to connect debate with action which is itself intrinsically related to speech. Action, as the highest form of human activity, presupposes human plurality. However, plurality here does not only mean an otherness of another, but rather the uniqueness of everyone when as individuals act. Given this analysis, the condition for plurality must be a public space in which everyone is equal. But equality as isonomy is not a natural attribute that human beings have, it is an artificial institution. Human beings in equality are not private persons but citizens. Aristotle has said, human beings in their essence are political animals. This also is true for Arendt and just in the sense Arendt writes "that the capacity to judge is a specifically political ability." [6]. Here we should be extremely careful, because citizens in the Greek polis only limit to the adult free men. In other words, slaves, women, and young men are not citizens. But in modern age everyone is citizen which consists of all people in the earth. This is the achievement realized in the philosophy of the Enlightenment. "Their public freedom... could exist only in public; it was a tangible, worldly reality, something created by men to be enjoyed by men rather than a gift or a capacity, it was the man-made public space or market-place which antiquity had known as the area where freedom appears and becomes visible to all." [7]. According to Arendt, there are two connotations in our public freedom. First of all, freedom is the man-made public space which is enjoyed by participants. Secondly, freedom is the freedom of all.

It is in this second connotation of public freedom that we can recognize that Arendt introduces the distinction between freedom and liberation. As to liberation, it is always liberation from something. For example, the oppressed people liberate themselves from oppressive rulers, or the starveling persons liberate themselves from the hardships of their lives. For this regard, liberation is always restricted to some groups or classes but never apply to all the people in which the rich and the rulers are included. In opposition to liberation, freedom is a positive conception that the participants achieve when they debate together and determine public affairs. From this perspective, it is dangerous and misleading to identify liberation with freedom. Arendt absolutely agrees that individuals should 
be liberated from poverty or oppression, but only liberation cannot be adequate to satisfy freedom. "Nothing, we might say today, could be more obsolete than to attempt to liberate mankind from poverty by political means; nothing could be more futile and more dangerous." [8]. This is the reason why Arendt brings in the distinction between the political and the social in order to remind us of distinguishing freedom from liberation.

\section{Opinion: The Object of Judgment}

Insofar as we properly understand what Arendt intends to convey with public freedom, the very material of politics, which is opinion, will come into prominence. Arendt traces the political significance of opinion back into ancient times, especially the Greek polis. There have been long history battles between opinion and truth. Opinion, that is, doxa, in ancient times, was distinguished from some scientific or philosophic truth which was called alatheia. But for Arendt the orthodox political philosophy did not do justice to opinion that is distinctive for politics, considering that politics was judged by the alien criteria of truth. In contemporary world, opinion is so distorted that by clouding the distinction between opinion and truth we even seek to undermine factual truths as if they were illusory opinions. Given this historical situation, Arendt reminds us of distinguishing opinion from truth. Unlike the truth which needs to be found, we do not have opinions but form them. "I form an opinion by considering a given issue from different viewpoints... The more people's standpoints I have present in my mind while I am pondering a given issue, and the better I can imagine how I would feel and think if I were in their place, the stronger will be my capacity for representative thinking and the more valid my final conclusions, my opinion." [5]. It is not adequate in the formation of opinions for us to think some given issues solely because opinion is not the private activity that is performed by the solitary thinker. So to say opinion is the stuff of politics is just to say that only in a political public place where thinkers are equal can they participate in public affairs with each other and form opinions by considering their issues from different viewpoints. Opinions can only be examined and enriched through encounter with other opinions. Whether it is a genuine tansaction or a imaginative one, the most crucial is to grasp the way of representative thinking in which engaged thinkers present to his or her mind the standpoints of those who are absent. Now we can say that which Arendt said about judging: "Judging is one, if not the most, important activity in which this sharing-the-world-with-others comes to pass." [9]. In other words, the representative thinking, which is the mode of thinking to form opinions, is judging. To judge then means that we come to share the world with others through opinions.

Opinion not only ought to be distinguished from truth, it also needs to be distinguished from interest. As we have indicated above, only with others or making their standpoints present to our minds are opinions for us formed. In this sense, there is no adequacy for opinions but the further judging or the better argument. This is the significance of opinion that Arendt wants to emphasize when 
she distinguishes opinion from interest. In the eyes of Arendt, interest is very different from opinion. Politically, interest is a conception that signifies the interest of some group or class. As a result, "for the purification of such group interests it seems to suffice that they are represented in such a way that their partial character is safe-guarded under all conditions, even under the condition that the interest of one group happens to be the interest of the majority." [10]. Contrary to interest, opinion is a political phenomenon exclusively about individuals. "No multitude, be it the multitude of a part or of the whole of society, will ever be capable of forming an opinion." [10]. Opinions move beyond the limited interests of some group which even happens to be the multitude of the whole of society and belong to all individuals. Compared with each of our human beings only being a number in group interests, opinions belong to every free man and woman.

\section{Taste: The Power of Judgment}

Based on what we have reached above, we now could more directly deal with what Arendt said about judgment. Although Arendt recognizes that there is an affinity between her judging and Aristotle's phronesis, the main inspiration of what she intends to say for judgment is derived from her highly original hermeneutic understanding of Kant's Critique of Judgment. Arendt said "what... is quite new and even startlingly new in Kant's propositions in the Critique of Judgment is that he discovered this phenomenon in all its grandeur precisely when he was examining the phenomenon of taste." [6]. For Arendt, taste, that is, reflective judgment, describes the power of judgment. In Kant's propositions in the Critique of Judgment reflective judgment represents the mode of judging that particulars are not subsumed under universal rules but ascended to universals. Such judgment makes us to think in the view of everybody else. Kant's reflective judgment opens a new way to understand the validity of opinion which is different from the validity of truth. We can only "woo the consent of everyone else" because judgment is valid just "for every single judging person". In other words, judgment is nonsense for those who do not judge. Considering all of these, Kant bases judgment on taste, and this is consequential for Arendt to explain her own judgment. Taste not only can not be confused with "private feelings" and but need also to be distinguished from the kind of universality that is the characteristic of "cognitive reason". Taste in this sense is the type of community sense, that is, sensus communis. The validity of opinions then consists in the particularity of each opinion while making its claim to communal validity.

Drawing on what Kant says about taste, Arendt emphasizes that the validity of judgment depends on the power of agreement to which the communications with others eventually come. Power for Arendt ought to be distinguished from authority, force, strength, and violence. Authority itself will fail when force is used, because force is the use of external means of coercion. However, authority is also different from persuasion which requires equality and argumentation.

"Against the egalitarian order of persuasion stands the authoritarian order, which 
is always hierarchical." [11]. As to strength, Arendt suggested, it is the gift and the possession of every one in his or her solitary situation against all other persons. In all of these differences, violence is the furthest one distance from power insofar as it is always ready to destroy the required conditions for politics. Unlike authority, force, strength and violence, power is the consequences of participation where participants join themselves into the market place and argue with each other in the public realm. "Hence, binding and promising, combining and covenanting are the means by which power is kept in existence." [12].

Thus far, we just analyze what Arendt appropriates in Kant. But at the same time Arendt also realizes that Kant's taste was primarily regarded as the disinterested judgment of the pure spectator. What is distinctive for Arendt's judgment here is that we need to shift our attentions from the pure spectator to the participant in human affairs. Judging is closely corresponded to what Aristotle called phronesis, "the convincing and persuading speech which they regarded as the typically political form of people talking with one another." [13]. However, in the Greek polis, phronesis signified the specifically intellectual virtue only attributed to citizens in which slaves, women, and young men were not included. This is the reason why Arendt seeks to relate the spectator with the actor when she said that the "critic or spectator sits in every actor and fabricator; without this critical, judging faculty the doer or maker would be so isolated from the spectator that he would not even be perceived." [14]. David L. Marshall, who investigated the origin of Arendt's judgment, told us that "it would be a mistake to suppose that the judgment of the actor and the judgment of the spectator are necessarily incompatible." [15]. However, leaving aside the scholarly problem of whether it is ambiguous or not to at nonce speak of the spectator and of the actor, we can still pay attention to two positive significances that Arendt revealed for us in judgment. Appealing to Kant, Arendt discovered the taste which is applicable to all of people in the world. Compared with phronesis, Arendt discovered the praxis that reminds us of the man-made public space or market-place which antiquity had known as the area where freedom appears and becomes visible to all.

\section{Conclusion}

Throughout my exploration of freedom, opinion, and taste, I have sought to articulate the intrinsically relevant themes for comprehending what Arendt intended to say concerning judgment. As Gadamer has taught us in Truth and Method, if we would like to understand something, it is important to bring forth what makes the understanding possible. With regard to judgment in Arendt, the connotations of judgment consist of its context, i.e. freedom, its object, i.e. opinion, and its power, i.e. taste. The context of judgment is Arendt's historical situation in which she engages in illustrating what public freedom means in the modern age. Freedom not only is the freedom of all but also is the man-made public place. The object of judgment is Arendt's political stuff that is not only distinguished from truth but also from interest. Opinion, on the one hand, signi- 
fies a distinctive validity claim that is formed by considering a given issue from different standpoints within participants. On the other hand, opinion is an entirely different political phenomenon from interest. Contrary to interests, which are relevant merely as group interests, opinions exclusively belong to individuals. Group represents the multitude of a part or of the whole of society. Individual symbolizes all of the free men and women. The power of judgment is Arendt's thinking process which is not the thought process of pure reasoning but the communication process of achieving agreement. Taste, for Kant, is the specific validity of judgment not the universal validity of cognition. Basing judgment on taste helps Arendt come up with a mode of thinking that could ascend from particular to universal. Taste for Arendt is primarily not the disinterested judgment of the pure spectator but rather the political power of the participant actor. There is no mystery to Arendt that we could reconcile the spectator and the actor because these two seemingly different perspectives are essentially the fundamental elements in human condition. No matter freedom, opinion, or taste, there are always two respects that Arendt implicitly or explicitly at once emphasizes. The first one concerns the universality of human beings and the second one concerns the historicity of human beings. It is the integrity of human beings that determines the unity of judgment.

\section{Conflicts of Interest}

The author declares no conflicts of interest regarding the publication of this paper.

\section{References}

[1] Bernstein, R.J. (2018) Why Read Hannah Arendt Now. Polity Press, Cambridge, 1.

[2] Arendt, H. (1993) Crisis in Culture. In: Between Past and Future, Penguin Books, New York, 220.

[3] Arendt, H. (1993) Truth and Politics. In: Between Past and Future, Penguin Books, New York, 227-264.

[4] Bernstein, R.J. (1983) Beyond Objectivism and Relativism: Science, Hermeneutics, and Praxis. University of Pennsylvania Press, Philadelphia, PA, 218.

[5] Arendt, H. (1993) Truth and Politics. In: Between Past and Future, Penguin Books, New York, 241.

[6] Arendt, H. (1993) Crisis in Culture. In: Between Past and Future, Penguin Books, New York, 221.

[7] Arendt, H. (1963) On Revolution. Viking Press, New York, 120-121.

[8] Arendt, H. (1963) On Revolution. Viking Press, New York, 110.

[9] Arendt, H. (1993) Crisis in Culture. In: Between Past and Future, Penguin Books, New York, 221.

[10] Arendt, H. (1963) On Revolution. Viking Press, New York, 229.

[11] Arendt, H. (1993) What Is Authority? In: Between Past and Future, Penguin Books, New York, 93.

[12] Arendt, H. (1963) On Revolution. Viking Press, New York, 174. 
[13] Arendt, H. (1993) Crisis in Culture. In: Between Past and Future, Penguin Books, New York, 222.

[14] Arendt, H. (1978) Appendix: Judging. In: The Life of the Mind, Harcourt Brace Jovanovich, New York, 262.

[15] Marshall, D.L. (2010) The Origin and Character of Hannah Arendt's Theory of Judgment. Political Theory, 38, 367-393. https://doi.org/10.1177/0090591709359595 